\title{
ГИДРОЭКОЛОГИЧЕСКИЕ ОСОБЕННОСТИ ПОВЕРХНОСТНЫХ ВОД УГЛЕПРОМЫШЛЕННЫХ ТЕРРИТОРИЙ ВОСТОЧНОГО ДОНБАССА
}

\author{
(C) 2020 г. В. Е. Закруткин ${ }^{a}$, О. С. Решетняк ${ }^{a, b}, *$ Е. Н. Бакаева ${ }^{a, b, c}$ \\ ${ }^{a}$ Южный федеральный университет, Ростов-на-Дону, Россия \\ ${ }^{b}$ Гидрохимический институт, Ростов-на-Дону, Россия \\ ${ }^{c}$ Институт водных проблем РАН, Ростов-на-Дону, Россия \\ *e-mail: olgare1@mail.ru \\ Поступила в редакцию 21.07.2019 г. \\ После доработки 29.11.2019 г. \\ Принята к публикации 30.01.2020 г.
}

\begin{abstract}
На основе данных гидрохимических исследований и оценки токсичности поверхностных вод по результатам биотестового анализа разработан новый подход к оценке качества вод рек Восточного Донбасса в зоне влияния техногенных шахтных вод. Основу подхода составляет использование регионального фона, комплекса гидрохимических и биотестовых данных по набору биотестов. Разработана шкала интегральной оценки качества вод с выделением 5 классов. Оценочная шкала учитывает степень загрязненности вод по аналитическим данным и степень токсичности. Оценки качества воды показали, что в пределах бассейнов Северского Донца и Тузлова в целом оно меняется от 2-го класса (“слабо загрязненные”) до 4-го класса (“сильно загрязненные”), а по данным о степени токсичности - от 1-го класса (“условно нетоксичные") до 3-го класса ("токсичные”). Данные аналитических методов не всегда согласуются с результатами биотестового анализа, что связано с различной биодоступностью загрязняющих веществ для биоты. Итоговую оценку качества речных вод надо проводить с учетом их класса по гидрохимическим данным с указанием возможной биодоступности токсикантов для гидробионтов.
\end{abstract}

\begin{abstract}
Ключевые слова: качество воды, гидрохимические исследования, биотестирование, степень токсичности, фоновые концентрации, суммарный показатель загрязнения, биодоступность токсиканта, интегральная оценка, реки Восточного Донбасса, техногенные шахтные воды
\end{abstract}

DOI: $10.31857 / \mathrm{S} 2587556620030139$

\section{ПОСТАНОВКА ПРОБЛЕМЫ}

Основным инструментом оценки качества поверхностных вод являются предельно допустимые концентрации (ПДК) загрязняющих веществ. Если содержание того или иного вещества превышает ПДК, то качество водной среды считается неудовлетворительным и необходимо принимать меры по снижению уровня загрязнения водного объекта. Несмотря на многочисленную критику ПДК $[3,4,8,16]$, данный норматив используется повсеместно в системе экологического нормирования химического загрязнения водных экосистем, оценке качества воды и состояния водных объектов. В поверхностные водные объекты поступает более 200 тыс. различных веществ и этот список пополняется новыми синтезированными соединениями, в то время как значения ПДК установлены только для 10\% химических веществ [8].

Использование системы ПДК не позволяет оценить реальное влияние на экологическое со- стояние водных объектов кратности превышения ПДК и длительности воздействия высоких концентраций загрязняющих веществ. Не учитываются также эффекты влияния на биоту отдельных загрязняющих веществ, проявление токсичных свойств которых зависит от конкретной гидрохимической обстановки в водном объекте [8]. Так, например, токсические свойства многих тяжелых металлов и алюминия могут значительно меняться в зависимости от температуры, кислотности, окислительно-восстановительных условий и жесткости воды [18, 19].

Нормативы ПДК химических веществ разработаны без учета регионального фонового их содержания в поверхностных водах, наличия территорий с повышенным или пониженным содержанием отдельных элементов (геохимические аномалии) и т.п. Поэтому использование единых ПДК при проведении различных прогнозных оценок не всегда корректно в силу завышения или занижения результатов оценки. Так, прогноз возможного ухудшения состояния водных экосистем с использо- 
ванием единых ПДК в районах с различными экологическими условиями может быть некорректен по следующим причинам [2, 3, 14, 16]:

- в отдельных экосистемах фоновые концентрации некоторых показателей на порядок превышают ПДК, но водные организмы адаптированы к ним, и трансформации их структуры и функций не происходит;

- некоторые химические соединения даже при содержании в воде ниже ПДК могут негативно влиять на отдельные популяции водных организмов.

Поэтому концепция ПДК уже на протяжении последних десятков лет подвергается справедливой критике и результаты оценки качества поверхностных вод оказываются не вполне достоверными [4, 9].

Для устранения этого несоответствия нами предлагается использовать региональный фон и новый комплексный подход к оценке качества речных вод Восточного Донбасса, основанный на использовании таких критериев оценки, как уровень загрязнения воды (по суммарному показателю загрязнения Zc относительно фона) и степень токсичности воды по трем биотестам.

Оценить токсическое загрязнение водных экосистем каким-либо одним из известных методических подходов (физико-химический, биологический) не представляется возможным, поскольку для получения адекватной картины необходимо изучить не только состояние гидробиоты, но и определить качество среды ее обитания, т.е. качество воды, одной из характеристик которой является токсичность [1].

Биотическая составляющая экосистем является базовой в изучении формирования и восстановления качества вод в условиях антропогенной нагрузки. Только биота может дать ответ о токсичности компонентов водной экосистемы, поскольку токсичность - характеристика биологическая. В настоящее время оценка токсичности пресноводных экосистем включена в число обязательных характеристик экологического состояния водных объектов многих европейских государств и США [1]. Однако биотестирование дает ответ об общей токсичности вод без идентификации загрязняющих веществ. Качественный и количественный состав загрязняющих веществ определяют только аналитическими методами.

Вследствие сказанного нами предпринята попытка оценить качество поверхностных вод Восточного Донбасса с учетом их гидроэкологических особенностей, опираясь на комплекс гидрохимических и биотестовых данных.

\section{МАТЕРИАЛЫ И МЕТОДИКА ИССЛЕДОВАНИЙ}

Поверхностные воды Восточного Донбасса в пределах Ростовской области представлены, в основном, малыми реками бассейнов Тузлова и Северского Донца. Они расположены на территории, где представлена угледобывающая промышленность, претерпевающая реструктуризацию с 1990 г. Длительная разработка угольных месторождений и последующее закрытие шахт "мокрым способом” привели к формированию серьезных гидроэкологических проблем в регионе, связанных с воздействием техногенных шахтных вод на поверхностные воды. Шахтные воды агрессивны, поскольку они имеют в своем составе спектр тяжелых металлов, низкую рН и высокоминерализованы $[5,6]$.

Исследованиями охвачены реки двух бассейнов на территории Восточного Донбасса в пределах Ростовской области: Северского Донца рр. Калитва, Кундрючья, Быстрая, Лихая, Большая Гнилуша, Большая и Малая Каменка, и Тузлова - pр. Большой и Малый Несветай, Аюта, Грушевка, Кадамовка и Атюхта. Эти реки испытывают разный уровень антропогенного воздействия, в первую очередь, со стороны сельского хозяйства и объектов угледобывающей промышленности. Особое внимание уделено малым и средним рекам региона, так как именно они формируют более крупные водотоки, имеют более низкую самоочищающую способность и являются чувствительным индикатором антропогенного воздействия и экологического состояния водосборных территорий.

В основу работы положены результаты изучения степени токсичности и загрязненности вод тяжелыми металлами, полученные в ходе комплексных экспедиционных исследований. Исследования проведены сотрудниками кафедры геоэкологии и прикладной геохимии Института наук о Земле ЮФУ, Института водных проблем РАН и Гидрохимического института в 2014-2016 гг.

Створы отбора проб расположены на трех основных участках рек: верховья, устья и ниже выхода шахтных вод (рис. 1). Кроме того, выбранные створы отражали различные виды антропогенной нагрузки: отсутствие промышленной нагрузки (наличие в большей степени сельскохозяйственной деятельности) в верховьях рек, воздействие техногенно измененных шахтных вод в местах ниже их выхода, хозяйственно-бытовая нагрузка населенных пунктов, устья рек.

Отбор проб поверхностных вод для гидрохимических исследований проводился согласно ГОСТ 17.1.3.07-82 и ГОСТ 17.1.5.01-80. На малых и средних реках при однородном химическом составе воды отбор проб проводился на стрежне во- 


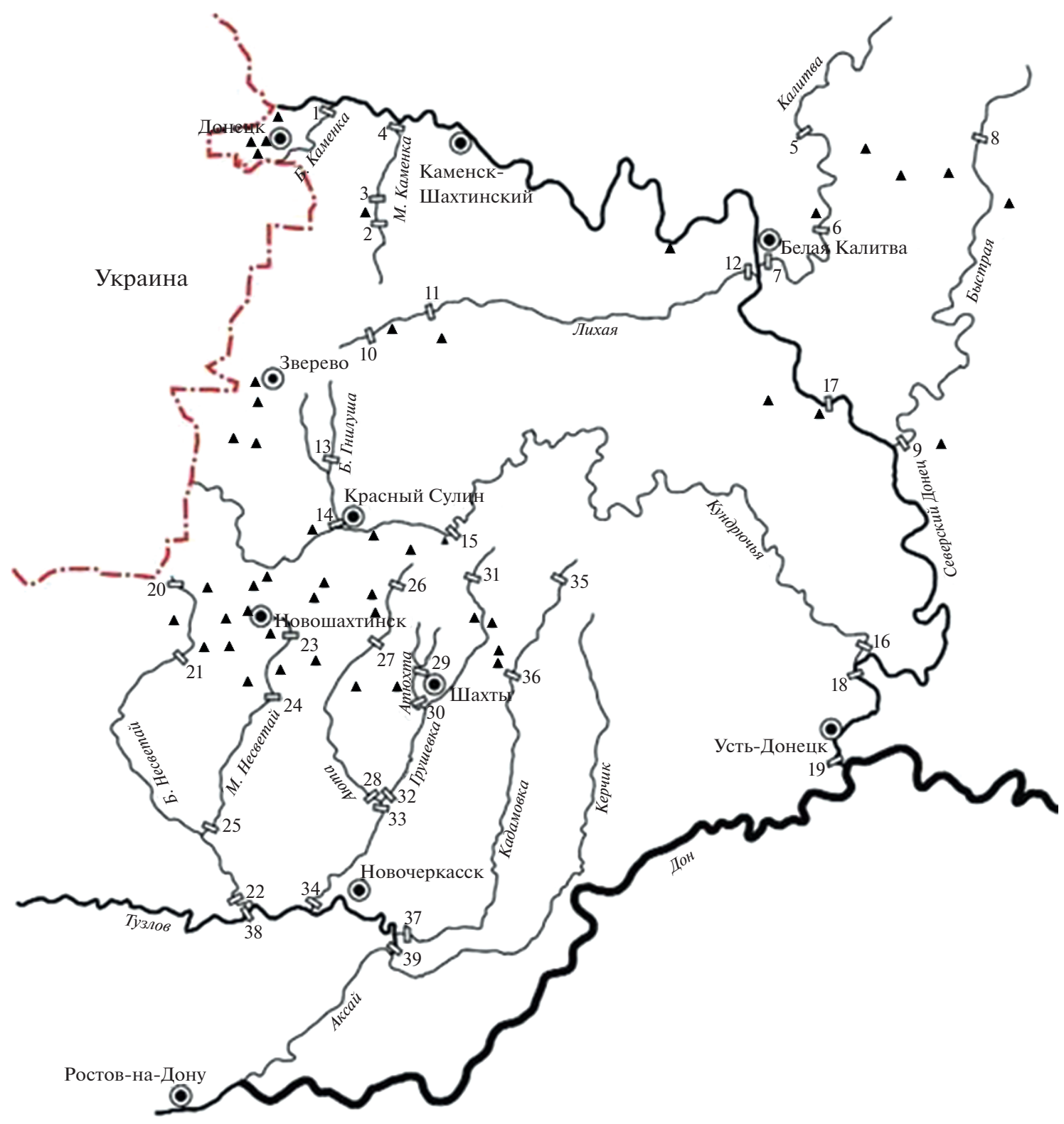

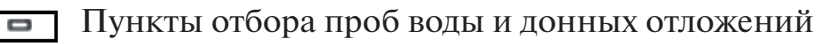
Угольные шахты

Рис. 1. Схема расположения точек отбора проб воды и донных отложений рек Восточного Донбасса.

дотока, в поверхностном слое воды на глубине до 50 см. Объем взятой пробы воды (1.5 л) соответствовал установленным нормативным документам с учетом количества определяемых показателей и возможности проведения повторного исследования. Для хранения и транспортировки гидрохимических проб использована темная стеклянная посуда с герметически закрывающимися крышками.

Химический анализ воды выполнялся по методикам, допущенным для целей государственного экологического контроля. Растворенные формы металлов в природной воде определялись атомноабсорбционным спектрофотометром "Квант2МТ” по методикам ПНД Ф 14.1:2:4.214-06 и ПНД Ф 14.1:2:4.138-98.

Установление токсичности поверхностных вод проводили методом биотестирования с помощью набора из трех биотестов в соответствии с руководящими документами Росгидромета [10-12], согласно которым рекомендовано при использовании набора биотестов оценку токсичности вод 
проводить по тест-объекту (или тест-показателю), проявившему наибольшую чувствительность.

Оценивали воды как оказывающие или неоказывающие острое (ОТД), подострое (пОТД) и хроническое (ХТД) токсическое действие, поскольку биотестирование позволяет получить оценку суммарного (интегрального) качества воды по их способности оказывать токсическое действие на представителей гидробиоты и не предусматривает идентификацию отдельных загрязняющих веществ.

\section{РЕЗУЛЬТАТЫ ИССЛЕДОВАНИЙ И ИХ ОБСУЖДЕНИЕ}

Как уже отмечалось ранее [5-7], поверхностные воды Восточного Донбасса отличаются высокой минерализацией (от 1.0 до 6.8 г/дм³), обусловленной, в первую очередь, очень высокими концентрациями сульфатов, ионов натрия и калия. Повышение минерализации воды и изменение ее химического состава прослеживается в большей степени на тех участках рек в бассейнах Северского Донца и Тузлова, которые находятся в зоне непосредственного техногенного влияния объектов угледобычи. В целом же речные воды исследуемых бассейнов имеют нейтральную или слабо щелочную кислотность среды (6.5-8.5) и достаточное содержание растворенного в воде кислорода (от 6.8 до 14.9 мг/дм³).

Из числа макрокомпонентов достаточно стабильная загрязненность речных вод Восточного Донбасса наблюдается по сульфатам $\left(\mathrm{SO}_{4}^{2-}\right)$, сумме ионов $\mathrm{Na}^{+}+\mathrm{K}^{+}$и ионам $\mathrm{Mg}^{2+}$. Максимальные значения этих компонентов достигали соответственно 3360 мг/дм ${ }^{3}$ (33.6 ПДК) - р. Атюхта, 1258 мг/дм ${ }^{3}$ (7.4 ПДК) - р. Атюхта и 172 мг/дм ${ }^{3}$ (7.4 ПДК) p. Аюта [5].

Поверхностные воды в пределах угленосных территорий обогащаются также микроэлементами, особенно марганцем, алюминием, железом, медью и стронцием. Именно металлы этой группы представляют наибольшую опасность для поверхностных вод Восточного Донбасса, поскольку загрязнение ими носит устойчивый характер, а уровень загрязненности - высокий и экстремально высокий. Нередки случаи высокого (В3) и экстремально высокого уровня загрязненности (ЭВ3) вод этими металлами. Содержание их в воде рек в отдельных створах достигало в 2014-2015 гг. уровней В3 по $\mathrm{Fe}$ (1 случай в р. Грушевка), Al (5 случаев в pp. Аюта, Большая Гнилуша, Грушевка, Кадамовка и Кундрючья), Мn (18 случаев В3), $\mathrm{Sr}$ (12 случаев В3) и всего 5 случаев ЭВ3 по Мn (3 в pp. Аюта, Кадамовка и Малая Каменка) и $\mathrm{Cd}$ (2-в р. Грушевка) [5, 13].
Если рассматривать гидроэкологическую ситуацию по бассейнам в целом, можно отметить более высокую комплексность и уровень загрязненности воды рек в бассейне Тузлова. Здесь к наиболее загрязненным следует отнести рр. Аюта, Кадамовка и Грушевка. Причем последняя, по данным за 2014-2015 гг., характеризуется высоким уровнем загрязненности воды и наибольшим количеством случаев В3 и ЭВ3. Наиболее загрязненными водотоками в бассейне Северского Донца являются р. Кундрючья и ее приток р. Большая Гнилуша. Можно также выделить реки, состояние которых характеризуется как наиболее благополучное: это рр. Северский Донец и Быстрая, а также верховья рр. Большой Несветай и Кадамовка в бассейне Тузлова [5].

Важнейшим этапом в изучении качества речных вод с учетом региональных особенностей является установление для них фоновых значений гидрохимических показателей. Решение этой задачи часто сопряжено с определенными трудностями, в первую очередь - с выбором водных объектов для характеристики фона. Последние должны располагаться за пределами влияния источников загрязнения и формировать химический состав воды в аналогичных природных условиях, что и исследуемые реки. В соответствии с этими критериями пробы воды в бассейнах Тузлова и Северского Донца для оценки фоновых характеристик отбирались либо в верховьях малых рек, либо на их притоках, но в любом случае выше зоны возможного влияния антропогенных источников (в первую очередь объектов угольной промышленности).

Фоновые концентрации макро- и микрокомпонентов (табл. 1) для рек бассейна Северского Донца рассчитаны по данным двух участков р. Калитва (выше устья балки Обливинской у хут. Рудаков) и р. Быстрая (северная окраина хут. Карпово-Обрывский), для бассейна Тузлова р. Большой Несветай (выше выхода шахтных вод ш. “Соколовская”, северная окраина хут. Черников).

При оценке загрязненности речных вод по отношению к фону за основу взят суммарный показатель загрязненности $(\mathrm{Zc})$ воды, аналогичный суммарному показателю загрязнения водных экосистем по интенсивности накопления металлов в донных отложениях [15, 17]. Градации уровня загрязненности поверхностных вод приняты в соответствии с классификационной шкалой, приведенной в [17], а именно: “слабый”, “средний”, “высокий” и “очень высокий”. Результаты расчета Zc воды позволили сгруппировать исследуемые реки в бассейнах Северского Донца и Тузлова в три группы по каждому бассейну. Результаты группировки представлены в табл. 2. Полученная классификация рек вполне согласу- 
Таблица 1. Фоновые концентрации химических веществ для речных вод Восточного Донбасса

\begin{tabular}{|c|c|c|c|c|c|c|}
\hline \multicolumn{7}{|c|}{ Фоновые концентрации по макрокомпонентам, мг/дм³ } \\
\hline $\mathrm{Na}^{+}+\mathrm{K}^{+}$ & $\mathrm{Ca}^{2+}$ & $\mathrm{Mg}^{2+}$ & $\mathrm{Cl}^{-}$ & $\mathrm{SO}_{4}^{2-}$ & Минерализация & Железо \\
\hline \multicolumn{7}{|c|}{ Бассейн Северского Донца } \\
\hline 129 & 151 & 30 & 203 & 361 & 1112 & 0.25 \\
\hline \multicolumn{7}{|c|}{ Бассейн Тузлова } \\
\hline 242 & 149 & 71 & 30 & 982 & 1983 & 0.26 \\
\hline \multicolumn{7}{|c|}{ Фоновые концентрации по микрокомпонентам, мг/дм³ } \\
\hline $\mathrm{Al}$ & $\mathrm{Be}$ & $\mathrm{Cd}$ & $\mathrm{Li}$ & $\mathrm{Mn}$ & $\mathrm{Cu}$ & $\mathrm{Sr}$ \\
\hline \multicolumn{7}{|c|}{ Бассейн Северского Донца } \\
\hline 0.14 & 0.0003 & 0.0003 & 0.015 & 0.13 & 0.002 & 1.35 \\
\hline \multicolumn{7}{|c|}{ Бассейн Тузлова } \\
\hline 0.22 & 0.0007 & 0.0004 & 0.020 & 0.04 & 0.002 & 2.31 \\
\hline
\end{tabular}

Таблица 2. Группировка рек Восточного Донбасса по уровню загрязненности вод

\begin{tabular}{|c|c|c|}
\hline Значение Zc & Участки рек & Уровень загрязненности воды \\
\hline \multicolumn{3}{|c|}{ Бассейн Северского Донца } \\
\hline До 10 & $\begin{array}{l}\text { “Фоновые участки” рр. Быстрая и Калитва } \\
\text { Участки рр. Малая Каменка }\end{array}$ & Слабый \\
\hline $10-20$ & Участки рр. Большая Каменка, Лихая & Средний \\
\hline Более 20 & Участки рр. Большая Гнилуша и Кундрючья & Средний или сильный \\
\hline \multicolumn{3}{|c|}{ Бассейн Тузлова } \\
\hline До 30 & $\begin{array}{l}\text { “Фоновый участок” р. Большой Несветай. Участки } \\
\text { рр. Грушевка, Кадамовка }\end{array}$ & Слабый или средний \\
\hline $30-50$ & Участки рр. Аюта, Кадамовка и Малый Несветай & Сильный \\
\hline Более 50 & Участки рр. Кадамовка и Атюхта & Очень сильный \\
\hline
\end{tabular}

ется с ранее полученными данными об особенностях и различиях в химическом составе воды двух бассейнов и качестве речных вод [5-7].

Анализы полученных данных по расчету загрязненности воды Zc воды (абсолютному значению показателя) и группировке рек позволили выделить следующие уровни загрязненности и определить диапазоны изменения суммарного показателя загрязнения поверхностных вод Восточного Донбасса:

- Zc $\leq 2$ - "условно чистая" вода;

$-\mathrm{Zc}=2-10$ - “слабый уровень загрязнености";

- Zc = 11-30 - "средний уровень загрязнености";

- $\mathrm{Zc}=31-50-$ "сильный уровень загрязнености";

- Zc > 50 - “очень сильный уровень загрязнености".
Затем по соответствующим значениям Zc выделены пять классов качества воды: от 1 до 5. Дана вербальная характеристика качества вод по уровню загрязненности в диапазоне от "условно чистых” (1-й класс качества) до “очень сильно загрязненных" (5-й класс).

Затем выполнена оценка токсичности поверхностных вод изучаемой территории по результатам биотестового анализа с использованием трех биотестов. Итоговую оценку токсичности вод рекомендовано проводить по тест-объекту (или тест-показателю), проявившему наибольшую чувствительность. Такой способ оценки выявляет наиболее слабое звено в экосистеме, например, автотрофы, фильтраторы из гетеротрофов, или один из двух использованных близкородственных видов (хлорелла и сценедесмус - представители фитопланктона). Так, по результатам экспедиционных исследований 2015 г. токсичность вод во всех створах фиксировалась только по одному биотесту с автотрофами - микроводорослевым 
Таблица 3. Количество проб с разной степенью токсичности (\% от общего количества проб) по данным биотестов

\begin{tabular}{l|c|c}
\hline \multicolumn{1}{c|}{$\begin{array}{c}\text { Степень } \\
\text { токсичности }\end{array}$} & $\begin{array}{c}\text { Бассейн } \\
\text { р. Тузлов }\end{array}$ & $\begin{array}{c}\text { Бассейн } \\
\text { р. Северский Донец }\end{array}$ \\
\hline Нет токсического & 33 & 21 \\
действия & & 47.4 \\
ОТД & 45 & 31.6 \\
пОТД & 22 & 79 \\
Всего токсичных & 67 & \\
проб & & \\
\hline
\end{tabular}

Примечание: ОТД - острое токсическое действие, пОТД подострое токсическое действие.

тест-объектом Chlorella vulgaris. Согласно такому подходу воды малых рек обоих бассейнов обладали высокой степенью токсичности: оказывали острое и подострое токсическое действие (табл. 3).

Следует подчеркнуть, что в таком случае неучтенной остается важная информация по двум другим биотестам, отличная от слабого звена, но которую также необходимо принимать во внимание. В связи с этим нами разработана шкала оценки качества вод с учетом данных трех используемых биотестов (табл. 4).

Подклассы токсичности вод выделены с учетом того, что различные виды живых организмов по-разному реагируют на одни и те же загрязняющие вещества. Для получения более объективной оценки биотестирование токсичности проводят на трех биотестах с использованием в качестве тест-объектов гидробионтов, принадлежащих к различным трофическим уровням и систематической принадлежности. Степень токсичности (острая, подострая, хроническая) могут не совпадать по результатам разных биотестов. В предлагаемой шкале отличия в ответах биотестов учтены. В связи с этим в шкале предусмотрены возможные варианты сочетаний выявленной степени токсичности по трем биотестам и проведено деление на классы (от 1 до 5) и более детальное - на подклассы. Степень токсичности вод каждого класса характеризуется в диапазоне от "условно нетоксичной” до “экстремально токсИЧной".

Сопоставление результатов оценки степени загрязненности речных вод по гидрохимическим показателям и степени токсичности воды позволило разработать шкалу комплексной оценки состояния и качества воды по этим показателям (см. табл. 4). В случае несовпадения классов по химическим и биотестовым данным следует учитывать, во-первых, что аналитический анализ не способен охватить весь спектр загрязняющих веществ, содержащихся в речной воде; во-вторых, для живых объектов важны не только концентрации токсикантов, но и их биодоступность. В связи с этим при окончательной оценке качества воды при высокой степени загрязненности химическими веществами, но низкой степени токсичности указывают класс по химическим данным и добавляют “с низкой биодоступностью токсикантов" (НБТ). В случае “хорошего” качества воды по химическим данным, но высокой

Таблица 4. Шкала интегральной оценки качества вод с учетом степени токсичности и загрязненности водной среды

\begin{tabular}{|c|c|c|c|c|c|c|c|}
\hline \multirow[b]{2}{*}{ № } & \multirow{2}{*}{$\begin{array}{c}\text { Варианты сочетаний } \\
\text { выявленной степени } \\
\text { токсичности вод } \\
\text { по трем биотестам }\end{array}$} & \multicolumn{2}{|c|}{$\begin{array}{c}\text { Токсичность вод по трем } \\
\text { биотестам }\end{array}$} & \multicolumn{3}{|c|}{$\begin{array}{c}\text { Загрязненность вод } \\
\text { по отношению к фону }\end{array}$} & \multirow{2}{*}{$\begin{array}{c}\text { Качество воды* } \\
\text { (класс } \\
\text { качества) }\end{array}$} \\
\hline & & $\begin{array}{c}\text { Класс } \\
\text { качества }\end{array}$ & $\begin{array}{c}\text { Степень } \\
\text { токсичности вод }\end{array}$ & $\begin{array}{c}\text { Значение } \\
\text { Zc }\end{array}$ & $\begin{array}{c}\text { Класс } \\
\text { качества }\end{array}$ & $\begin{array}{c}\text { Степень } \\
\text { загрязненности } \\
\text { вод }\end{array}$ & \\
\hline 1 & 3 нет ТД & 1 & Условно нетоксичные & Менее 2 & 1 & $\begin{array}{l}\text { Условно } \\
\text { чистые }\end{array}$ & $\begin{array}{c}\text { Очень хорошее } \\
\text { (1) }\end{array}$ \\
\hline 2 & $\begin{array}{l}2 \text { нет ТД + 1ХТД } \\
1 \text { нет ТД + } 2 \text { ХТД }\end{array}$ & $\begin{array}{l}2 \mathrm{a} \\
26\end{array}$ & Слабо токсичные & $2-10$ & 2 & $\begin{array}{l}\text { Слабо } \\
\text { загрязненные }\end{array}$ & $\begin{array}{c}\text { Хорошее } \\
(2)\end{array}$ \\
\hline 3 & $\begin{array}{l}\text { 2-3 пОТД } \\
1 \text { ОТД }\end{array}$ & $\begin{array}{l}3 \mathrm{a} \\
36\end{array}$ & Токсичные & $11-30$ & 3 & $\begin{array}{l}\text { Средне } \\
\text { загрязненные }\end{array}$ & $\begin{array}{l}\text { Среднее } \\
\text { (3) }\end{array}$ \\
\hline 4 & $\begin{array}{l}1 \text { пОТД + } 2 \text { ОТД } \\
2 \text { пОТД + 1ОТД }\end{array}$ & $\begin{array}{l}4 a \\
46\end{array}$ & Очень токсичные & $31-50$ & 4 & $\begin{array}{l}\text { Сильно } \\
\text { загрязненные }\end{array}$ & $\begin{array}{c}\text { Плохое } \\
\text { (4) }\end{array}$ \\
\hline 5 & 3 ОТД & 5 & $\begin{array}{l}\text { Экстремально ток- } \\
\text { сичные }\end{array}$ & Более 50 & 5 & $\begin{array}{l}\text { Экстремально } \\
\text { загрязненные }\end{array}$ & $\begin{array}{l}\text { Очень плохое } \\
\text { (5) }\end{array}$ \\
\hline
\end{tabular}

Примечание: ТД - токсическое действие, ХТД - хроническое токсической действие, пОТД - подострое токсическое действие, ОТД - острое токсическое действие.

* В случае несовпадения классов качества по химическим и биотестовым данным окончательная оценка складывается из класса по химическим данным с дальнейшим указанием о биодоступности токсикантов: ВБТ - высокая биодоступность токсикантов, НБТ - низкая биодоступность токсикантов. 
Таблица 5. Интегральная оценка состояния и качества речных вод по степени загрязненности и токсичности вод рек Восточного Донбасса

\begin{tabular}{|c|c|c|c|c|c|c|}
\hline \multirow{2}{*}{ Река } & \multirow{2}{*}{$\begin{array}{c}\text { Тип } \\
\text { створа* }\end{array}$} & \multicolumn{2}{|c|}{ Степень загрязненности } & \multicolumn{2}{|c|}{ Степень токсичности } & \multirow{2}{*}{$\begin{array}{l}\text { Качество воды } \\
\text { (класс качества) }\end{array}$} \\
\hline & & Значение Zc & Класс качества & Результаты & Класс качества & \\
\hline \multicolumn{7}{|c|}{ Бассейн Северского Донца } \\
\hline Большая Каменка & Устьевой & 15.0 & 3 & 2 ОТД & 36 & Среднее (3) \\
\hline \multirow[t]{2}{*}{ Большая Гнилуша } & Устьевой & 38.1 & 4 & 1 ОТД & $3 a$ & Плохое (4) \\
\hline & Нижний & 33.5 & 4 & 1 пОТД & $3 a$ & Плохое (4) \\
\hline Быстрая & Устьевой & 8.3 & 2 & 2 пОТД & $4 a$ & Хорошее (2) с ВБТ \\
\hline Калитва & Устьевой & 4.7 & 2 & 2 пОТД & 36 & Хорошее (2) с ВБТ \\
\hline \multirow{2}{*}{ Кундрючья } & Устьевой & 28.0 & 3 & 1 ОТД & $3 a$ & Среднее (3) \\
\hline & Нижний & 48.6 & 4 & 1 пОТД & $3 a$ & Плохое (4) \\
\hline \multirow[t]{3}{*}{ Лихая } & Устьевой & 14.9 & 3 & 3 пОТД & $3 \mathrm{a}$ & Среднее (3) \\
\hline & Нижний & 13.2 & 3 & 1 ОТД & 36 & Среднее (3) \\
\hline & Верхний & 14.6 & 3 & 1 ОТД & 36 & Среднее (3) \\
\hline \multirow[t]{3}{*}{ Малая Каменка } & Устьевой & 5.1 & 2 & нет ТД & 1 & Хорошее (2) с НБТ \\
\hline & Нижний & 15.6 & 3 & 1 пОТД & 1 & Среднее (3) с НБТ \\
\hline & Верхний & 10.1 & 2 & нет ТД & 36 & Хорошее (2) с ВБТ \\
\hline \multirow[t]{2}{*}{ Северский Донец } & Устьевой & 11.4 & 3 & 1 пОТД & $3 a$ & Среднее (3) \\
\hline & Нижний & 5.6 & 2 & 1 пОТД & $3 a$ & Хорошее (2) с ВБТ \\
\hline \multicolumn{7}{|c|}{ Бассейн Тузлова } \\
\hline \multirow[t]{3}{*}{ Аюта } & Устьевой & 31.1 & 4 & | 1 ОТД & 36 & Плохое (4) \\
\hline & Нижний & 34.8 & 4 & 1 ОТД & 36 & Плохое (4) \\
\hline & Верхний & 45.2 & 4 & 1 ОТД & 36 & Плохое (4) \\
\hline \multirow{2}{*}{$\begin{array}{l}\text { Большой Несве- } \\
\text { тай }\end{array}$} & Устьевой & 32.5 & 4 & 1 ОТД & 36 & Плохое (4) \\
\hline & Нижний & 24.6 & 3 & 1 пОТД & $3 a$ & Среднее (3) \\
\hline \multirow[t]{3}{*}{ Грушевка } & Устьевой & 21.8 & 3 & 1 ОТД & 36 & Среднее (3) \\
\hline & Нижний & 21.3 & 3 & 1 пОТД + 1ХТД & $3 a$ & Среднее (3) \\
\hline & Верхний & 22.1 & 3 & нет ТД & 1 & Среднее (3) с НБТ \\
\hline \multirow[t]{3}{*}{ Малый Несветай } & Устьевой & 37.3 & 4 & 1 ОТД & 36 & Плохое (4) с НБТ \\
\hline & Нижний & 42.5 & 4 & 1 пОТД & 36 & Плохое (4) с НБТ \\
\hline & Верхний & 39.4 & 4 & 1 ОТД & 36 & Плохое (4) с НБТ \\
\hline Тузлов & Устьевой & 19.0 & 3 & 1 ОТД + 1пОТД & 36 & Среднее (3) \\
\hline Атюхта & Устьевой & 54.0 & 5 & 2 пОТД & $3 a$ & Плохое (5) с НБТ \\
\hline
\end{tabular}

* Тип створа: “верхний”, “нижний” - створ на участке выше или ниже сброса шахтных вод, “устьевой” - створ в устье реки. ВБТ - высокая биодоступность токсикантов, НБТ - низкая биодоступность токсикантов.

степенью токсичности указывают класс по химическим данным с добавлением "с высокой биодоступностью токсикантов” (ВБТ). Так, в случае 13-го классов качества воды по химическим данным и наличием подострой степени токсичности (пОТД) хотя бы в одной из проб, окончательную характеристику качества вод формулируют: “качество воды хорошее (2) с высокой биодоступностью токсикантов". В случае высокой загрязненности воды (4-5 классы качества) по химическим данным и наличия невысокой степени токсичности формулируют “качество воды плохое с низкой биодо- ступностью токсикантов”. В дальнейшем планируется уточнение подуровней, основанных на вариантах сочетания токсичности. В соответствии с разработанной шкалой проведена оценка качества поверхностных вод исследованных рек, результаты которой представлены в табл. 5.

Как видно из табл. 5, качество речных вод в пределах бассейна Северского Донца меняется от 2-го класса (“слабо загрязненные", например, фоновые реки бассейна Быстрая и Калитва) до 4-го класса (“сильно загрязненные” участки pp. Кундрючья и Большая Гнилуша), Тузлова - 
от 3-го класса (“средне загрязненные”) до 4-го класса, за исключением р. Атюхта.

По данным о степени токсичности, качество речных вод в пределах бассейнов Северского Донца и Тузлова меняется от 1-го класса "условно нетоксичные” до 3-го класса “токсичные”.

Класс качества вод исследованных рек оценен согласно разработанной шкале (см. табл. 4), и, как видим, не всегда данные аналитических методов согласуются с результатами биотестового анализа. Известно, что токсическое действие на гидробиоту определяется биодоступностью загрязняющих веществ. То есть наличие высоких концентраций загрязняющих веществ не обязательно и не во всех случаях проявляется в токсическом действии на живое. Итоговую оценку качества поверхностных вод надо проводить с учетом класса по гидрохимическим данным с указанием возможной биодоступности для гидробионтов.

Таким образом, наблюдения за гидроэкологической ситуацией в поверхностных водах Восточного Донбасса в зоне ликвидации шахт “мокрым” способом наряду с гидрохимическими методами должны дополняться современными биологическими методами, включающими в обязательном порядке биотестовый анализ. Биотестирование должно включать набор, как минимум, из трех тест-объектов, позволяющих оценить качество вод с учетом специфики химического состава воды и загрязнения водных объектов. Это связано с тем, что биотестирование позволяет получить суммарную (интегральную) оценку влияния всего комплекса загрязняющих веществ, находящихся в водной экосистеме, но часто не определяемых аналитически, и нередко оказывающих непредсказуемое воздействие на гидробиоту.

\section{ЗАКЛЮЧЕНИЕ}

На основе данных комплексных гидрохимических и экотоксикологических исследований разработан новый подход к оценке состояния и качества вод рек Восточного Донбасса в зоне влияния техногенных шахтных вод. Основу подхода составляет использование регионального фона, комплекса гидрохимических и биотестовых данных по набору биотестов. Итоговая интегральная оценка состояния вод проводится в соответствии с пятью классами качества воды по комплексу результатов аналитических данных и биотестов.

Предложенный подход позволяет получить более объективную информацию о качестве поверхностных вод. Так, впервые учтены особенности региона, поскольку все заложенные в классификацию критерии рассчитываются относительно фона. Впервые предложено оценивать качество вод по вариантам сочетаний токсичности, выявленной по набору из трех используемых биотестов с тест-объектами различной систематической принадлежности и трофических уровней.

Разработанная шкала интегральной оценки состояния и качества вод основана на результатах двух подходов: метода биотестирования токсичности вод и определения концентраций загрязняющих веществ в воде аналитическими методами в синхронно отобранных пробах.

\section{СПИСОК ЛИТЕРАТУРЫ}

1. Бакаева Е.Н., Никаноров А.М. Биологические подходы к оценке экотоксикологического состояния водных экосистем // Изв. ВУЗов. Северо-Кавказский регион. Естественные науки. 2015. № 1. C. $72-83$.

2. Булгаков Н.Г., Левич А.П., Максимов В.Н. Прогноз состояния экосистем и нормирование факторов среды в водных объектах Нижнего Дона // Изв. РАН. Сер. биол. 1995. № 2. С. 218-255.

3. Булгаков Н.Г., Левич А.П., Максимов В.Н. Региональный экологический контроль на основе биотических и абиотических данных мониторинга // Экологический мониторинг: Учеб. пособие / под ред. Д.Б. Гелашвили. Ч. 5. Нижний Новгород: Издво ННГУ, 1998. С. 93-259.

4. Вопросы экологического нормирования и разработка системы оценивания состояния водоемов: Материалы Объединенного Пленума Научного совета ОБН РАН по гидробиологии и ихитологии, Гидробиологического общества при РАН и Межведомственной ихтиологической комиссии. Москва, 30 марта 2011 г. / отв. ред. Д.С. Павлов, Г.С. Розенберг, М.И. Шатуновский. М.: Товарищество научных изданий КМК, 2011. 196 с.

5. Закруткин В.Е., Скляренко Г.Ю., Бакаева Е.Н., Решетняк O.C., Гибков Е.В., Фоменко Н.Е. Поверхностные и подземные воды в пределах техногенно нарушенных геосистем Восточного Донбасса: формирование химического состава и оценка качества. Ростов-н/Д.: Изд-во Южного федерального ун-та, 2016. 170 с.

6. Закруткин В.Е., Гибков Е.В., Скляренко Г.Ю., Решетняк O.C. Сравнительная оценка качества поверхностных и подземных вод Восточного Донбасса по гидрохимическим показателям // Изв. ВУЗов. Северо-Кавказский регион. Естественные науки. 2016. № 2. С. 91-99.

7. Закруткин В.Е., Решетняк О.С., Бабаян Г.Г., Гибков Е.В., Саакян Г.А., Решетняк В.Н. Современный химический состав и тенденции пространственновременной изменчивости качества речных вод Восточного Донбасса // Изв. ВУЗов. Северо-Кавказский регион. Естественные науки. 2017. № 2. C. 101-109.

8. Никаноров А.М. Научные основы мониторинга качества вод. СПб.: Гидрометеоиздат, 2005. 576 с.

9. Никаноров А.М., Брызгало В.А., Решетняк О.С., Косменко Л.С. Обоснование необходимости разработки региональных критериев оценки качества воды и состояния водных экосистем: Сб. трудов V 
Международного конгресса "Чистая вода. Казань" (26-28 марта 2014 г.). Казань: Типогр. ООО "Куранты", 2014. С. 149-152.

10. РД 52.24.566-94. Рекомендации. Методы токсикологической оценки загрязнения пресноводных экосистем. Введ. 1994-07-21. М.: ФСР Госкомгидромета, 1994. $130 \mathrm{c}$.

11. РД 52.24.635-2002. Методические указания. Проведение наблюдений за токсическим загрязнением донных отложений в пресноводных экосистемах на основе биотестирования. СПб.: Гидрометеоиздат, 2002. $31 \mathrm{c}$

12. РД 52.24.662-2004. Оценка токсического загрязнения природных вод и донных отложений пресноводных экосистем методами биотестирования с использованием коловраток. М.: Метеоагенство Росгидромета, 2006. 60 с.

13. Решетняк О.С., Закруткин В.Е., Гибков Е.В. Микроэлементы в речных водах Восточного Донбасса / Геоэкологические проблемы углепромышленных территорий: Сб. трудов научной конференции с международным участием (Ростов-на-Дону, 21-23 октября 2015 г.). Ростов-н/Д.: Изд-во Южного федерального ун-та, 2015. С. 283-295.

14. Решетняк О.С. Методические аспекты оценки изменчивости состояния речных экосистем / Актуальные проблемы наук о Земле: сб. трудов научной конференции студентов и молодых ученых с международным участием. Ростов-н/Д.: Изд-во Южного федерального ун-та, 2015. С. 407-409.

15. Сает Ю.Е., Ревич Б.А., Янин Е.П. и др. Геохимия окружающей среды. М.: Недра, 1990. 335 с.

16. Шитиков В.К., Розенберг Г.С., Зинченко Т.Д. Количественная гидроэкология: методы системной идентификации. Тольятти: ИЭВБ РАН, 2003. 463 с.

17. Янин Е.П. Техногенные геохимические ассоциации в донных отложениях малых рек (состав, особенности, методы оценки). М.: ИМГРЭ, 2002. 52 с.

18. Mauer F.L., Ellersieck M.R. Manuel of acute toxicity interpretation and data base for 410 chemical and 66 species of freshwater animals // US Dep. Interior, Fish and Wildlife Service, 1986. 63 p.

19. Schudoma D. Environmental Quality Objectives for Hazardous Substances in Aquatic Environment. Berlin: Unweltbundesamt, 2001. 181 p.

\title{
Surface Water Hydroecological Peculiarities of Eastern Donbass Coal-Mining Areas
}

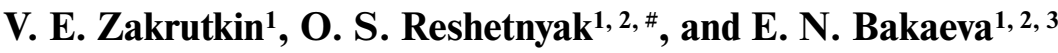 \\ ${ }^{1}$ South Federal University, Rostov-on-Don, Russia \\ ${ }^{2}$ Hydrochemical Institute, Rostov-on-Don, Russia \\ ${ }^{3}$ Water Problems Institute, Moscow, Russia \\ \#e-mail: olgare1@mail.ru
}

\begin{abstract}
For the first time a new approach has been developed to assess the water quality of the Eastern Donbass rivers in the zone of man-made mine waters' influence. The approach is based on the data of hydrochemical studies and surface water toxicity assessment by the results of biotest analysis. The approach basis is the use of regional background, a complex of hydrochemical and biotest data on a set of biotesting. The scale of water quality integrated assessment with the allocation of 5 classes has been developed. The rating scale takes into account water pollution degree according to analytical data and toxicity degree, including options for combining the results of the three bioassays. Water quality assessment results showed that within the Seversky Donets and Tuzlov basins it varies as a whole from the 2 nd class ("slightly polluted") to the 4th class ("heavily polluted"), according to the toxicity level-from 1st class ("conditionally non-toxic") to the 3rd class ("toxic"). Analytical methods data are not always consistent with biotest analysis results, which is associated with different bioavailability of pollutants to biome. The final river waters quality assessment should be carried out taking into account the waters class according to hydrochemical data and with indication of the possible toxicants' bioavailability for aquatic organisms.
\end{abstract}

Keywords: water quality, hydrochemical studies, biotest analysis, degree of toxicity, background concentrations, total pollution indicator, toxicant bioavailability, integral assessment, rivers of the Eastern Donbass, man-made mine waters

\section{REFERENCES}

1. Bakaeva E.N., Nikanorov A.M. Biological approaches to the assessment of the ecotoxicological state of aquatic ecosystems. Izv. Vuzov. Severo-Kavkazskii Reg., Ser. Estestv. Nauki, 2015, no. 1, pp. 72-83. (In Russ.).

2. Bulgakov N.G., Levich A.P., Maksimov V.N. Forecast of the state of ecosystems and rationing of environmental factors in water bodies of the Lower Don. Izv. Akad. Nauk, Ser. Biol., 1995, no. 2, pp. 218-255. (In Russ.).
3. Bulgakov N.G., Levich A.P., Maksimov V.N. Regional environmental control based on biotic and abiotic monitoring data. In Ekologicheskii monitoring [Environmental Monitoring], vol. 5. Gelashvili D.B., Ed. Nizhny Novgorod: Nizhegorodskii Gos. Univ., 1998, pp. 93-259. (In Russ.).

4. Voprosy ekologicheskogo normirovaniya $i$ razrabotka sistemy otsenivaniya sostoyaniya vodoemov [Problems of Environmental Regulation and Development of a Sys- 
tem for Assessing the State of Reservoirs]. Pavlov D.S., Rozenberg G.S., Shatunovskii M.I., Eds. Moscow: KMK Publ., 2011. 196 p.

5. Zakrutkin V.E., Sklyarenko G.Yu., Bakaeva E.N., Reshetnyak O.S., Gibkov E.V., Fomenko N.E. Poverkhnostnye i podzemnye vody $v$ predelakh tekhnogenno narushennykh geosistem Vostochnogo Donbassa: formirovanie khimicheskogo sostava i otsenka kachestva [Surface and Groundwater within the Technologically Disturbed Geosystems of the Eastern Donbass: the Formation of the Chemical Composition and Quality Assessment]. Rostov-on-Don: Yuzhn. Federal'n. Univ., 2016. $170 \mathrm{p}$.

6. Zakrutkin V.E., Gibkov E.V., Sklyarenko G.Yu., Reshetnyak O.S. Comparative assessment of the quality of surface and groundwater of Eastern Donbass by hydrochemical indicators. Izv. Vuzov. Severo-Kavkazskii Reg., Ser. Estestv. Nauki, 2016, no. 2, pp. 91-99. (In Russ.).

7. Zakrutkin V.E., Reshetnyak O.S., Babayan G.G., Gibkov E.V., Saakyan G.A., Reshetnyak V.N. Modern chemical composition and trends of spatial and temporal variability in the quality of river waters in Eastern Donbass. Izv. Vuzov. Severo-Kavkazskii Reg., Ser. Estestv. Nauki, 2017, no. 2, pp. 101-109. (In Russ.).

8. Nikanorov A.M. Nauchnye osnovy monitoringa kachestva vod [Scientific Basis for Water Quality Monitoring]. St. Petersburg: Gidrometeoizdat Publ., 2005. 576 p.

9. Nikanorov A.M., Bryzgalo V.A., Reshetnyak O.S., Kosmenko L.S. Rationale for the development of regional criteria for assessing water quality and the status of aquatic ecosystems. In Sbornik trudov V Mezhdunarodnogo kongressa "CHistaya voda. Kazan'” 26-28 marta 2014 g. [Proc. V Int. Congress "Clean Water. Kazan” 26-28 March 2014]. Kazan: Kuranty Publ., 2014, pp. 149-152. (In Russ.).

10. RD 52.24.566-94. Recommendations. Methods of Toxicological Assessment of Pollution of Freshwater Ecosystems. Moscow: FSR Goskomgidrometa, 1994. 130 p. (In Russ.).
11. RD 52.24.635-2002. Methodical Instructions. Observation of Toxic Pollution of Bottom Sediments in Freshwater Ecosystems Based on Biotesting. St. Petersburg: Gidrometeoizdat Publ., 2002. 31 p. (In Russ.).

12. RD 52.24.662-2004. Assessment of Toxic Pollution of Natural Waters and Bottom Sediments of Freshwater Ecosystems by Biotesting Using Rotifers. Moscow: Meteoagenstvo Rosgidrometa, 2006. 60 p. (In Russ.).

13. Reshetnyak O.S, Zakrutkin V.E., Gibkov E.V. Trace elements in the river waters of the Eastern Donbass. In Geoekologicheskie problemy uglepromyshlennykh territorii [Geoecological Problems of Coal-Mining Territories]. Rostov-on-Don: Yuzhn. Fed. Univ., 2015, pp. 283-295. (In Russ.).

14. Reshetnyak O.S. Methodological aspects of assessing the variability of river ecosystems. In Aktual'nye problemy nauk o Zemle [Actual Problems of Earth Sciences.]. Rostov-on-Don: Yuzhn. Fed. Univ., 2015, pp. 407409. (In Russ.).

15. Saet Yu.E., Revich B.A., Yanin E.P., et al. Geokhimiya okruzhayushchei sredy [Environmental Geochemistry]. Moscow: Nedra Publ., 1990. 335 p.

16. Shitikov V.K., Rozenberg G.S., Zinchenko T.D. Kolichestvennaya gidroekologiya: metody sistemnoi identifikatsii [Quantitative Hydroecology: Methods of System Identification]. Tolyatti: Inst. Ekol. Volzhskogo Basseina Akad. Nauk, 2003. 463 p.

17. Yanin E.P. Tekhnogennye geokhimicheskie assotsiatsii v donnykh otlozheniyakh malykh rek (sostav, osobennosti, metody otsenki) [Technogenic Geochemical Associations in Bottom Sediments of Small Rivers (Composition, Features, Assessment Methods)]. Moscow: IMGRE, 2002. 52 p.

18. Mauer F.L., Ellersieck M.R. Manual of Acute Toxicity Interpretation and Data Base for 410 Chemical and 66 Species of Freshwater Animals. US Department of the Interior, Fish and Wildlife Service, 1986. 63 p.

19. Schudoma D. Environmental Quality Objectives for Hazardous Substances in Aquatic Environment. Berlin: Unweltbundesamt, 2001. 181 p. 